\title{
Study on the relationship between small and micro hydropower cascade development and ecology
}

\author{
Liu Ruihua ${ }^{1}$, WangRong ${ }^{1}$, YangLi ${ }^{1}$, XiChuan ${ }^{1}$, LiuQunying ${ }^{2}$ \\ ${ }^{1}$ Sichuan Electric Vocational and Technical College, Chengdu Wenjiang, 610072 \\ ${ }^{2}$ School of Automation Engineering, University of Electronic Science and Technology of China Chengdu ,611731
}

\begin{abstract}
Micro hydropower and small hydropower are densely distributed, and coincide naturally with the core area of the ecological barrier. In view of the conflict of interests between small and micro hydropower and ecological equilibrium, and based on the existing research results of green small hydropower evaluation criteria, a relatively complete diagnostic index system of small and micro hydropower cascade development and ecological correlation is established from four aspects of environment, economy, management and sociality. The diagnostic index system of hair and ecology correlation suggests that people should not only develop and utilize water energy resources, but also give priority to the dream of protecting the natural ecological environment.
\end{abstract}

\section{Introduction}

China's hydropower resources ranking first in the world, China has been stepping up hydropower construction, and the scale of hydropower development has stepped up to a new level, with the reform and opening up. Southwest China is rich in small hydropower resource, where micro-hydropower and small hydropower are intensively distributed, and coincide with the core area of the ecological barrier. Meanwhile geological disasters are frequent and ecological fragility, which are also the areas with the richest biodiversity. Developing small hydropower can play an important role in solving the problem of power shortage in rural areas, promoting rural economic and social development and ensuring emergency power supply ${ }^{[1-3]}$. It is estimated that by 2020, the installed capacity of Sichuan province will be close to 10 million kilowatts. There are abundant water resources in Longmenshan ecological barrier area of Sichuan province. The main tributaries of Minjiang river run through the whole area like capillary network, and are being developed on a large scale. In addition to Zipingpu large-scale water conservancy project, a series of small and medium-sized hydropower stations are distributed step by step. Through the research at home and abroad, people have a new understanding of the view that hydropower is a clean energy source. With local climate changing, natural river break, fish migration interruption, river self-purification capacity decline and other ecological and environmental problems in the reservoir area have gradually attracted attention. However, domestic and foreign related research has mainly focused on large-scale projects represented by the three Gorges project, while little attention has been paid to small-scale cascade hydropower stations. In fact, the cumulative effect of small and micro hydropower stations is bound to have a long-term impact on Longmenshan ecological barrier, because of their large number and global distribution. Therefore, it is of great significance to study the correlation between cascade development of small hydropower and ecological civilization ${ }^{[4-8]}$.

\section{The correlation between cascade development of small and micro hydropower and environmental imbalance}

Most of the small-scale hydropower projects are mainly trans-basin diversion-type hydropower development. Except for a few hydropower stations with farmland irrigation, other comprehensive benefits have not been actively tapped. Since 2003, the development of small and medium-sized hydropower has turned to private mark. Coupled with inadequate management, the leapforward development of small and medium-sized hydropower enrichment areas in southwestern China has resulted in a short-term regional transitional development, resulting out-off-balance of the comprehensive development and utilization of hydropower resources and natural ecology.

The ecological imbalance caused by small and micro hydropower development is much more serious than that caused by large and giant hydropower, especially in areas with abundant ecological resources, such as the unique regional varieties of Chinese medicinal herbs, once destroyed, there is no regeneration, resulting in the loss of varieties of biological gene pool, and the value loss in all aspects is incalculable; in addition, there is no 
small and micro hydropower. Regulating function is often that there are too many discarded water and too much electricity shortage in the rainy season, which makes it difficult to guarantee the balance of power and electricity in small areas and to make full use of the advantages of resources to regulate and complement each other. Moreover, after the cascade development of diversion type hydropower in Jing River, the whole river is completely cut off and the natural and ecological balance in small areas is destroyed.

The optimization of the construction of small and micro hydropower stations is unscientific, and private investment does not focus on the investment of soil and water conservation and ecological environment control, which is easy to cause natural disasters such as landslides, soil erosion, floods and debris flows; moreover, if the hydropower stations are built and put into operation, the natural disasters will be even more serious if the control of soil erosion and the protection of ecological environment are not strengthened. The development and utilization of medium, small and micro hydropower projects have no reservoir capacity regulation, and the whole river basin has been cut off and dried up, thus breaking the natural ecological balance of the micro-area, and it is difficult to establish a new ecological balance in the small area.

\section{Diagnostic index system of cascade development and ecological correlation of small and micro hydropower stations}

Small and micro hydropower cascade development and ecological development is a multi-objective, whole process and multi-dimensional complex system engineering, so its index system is also a multi-level index system. Based on existing research results, a relatively complete diagnostic index system of small and micro hydropower cascade development and ecological correlation is established from four aspects of environment, economy, management and sociality, each of which contains a number of subordinate indicators. These four aspects can effectively reflect the coordination degree between small and micro hydropower cascade development and ecological development. The architecture is shown in Figure 1.

Because each index can only reflect one aspect of performance, for many indicators, each index has its own advantages and disadvantages, so it is impossible to give an overall evaluation by comparing each other. Therefore, it is necessary to use the comprehensive evaluation method to evaluate the diagnostic indicators of the correlation between cascade development of small and micro hydropower and ecological balance. A comprehensive evaluation method is used to synthesize projects of different nature which can not be directly summed up by means of certain methods and methods, and draw a general conclusion to comprehensively measure, diagnose and evaluate the coordinated development level of small and micro hydropower cascade development and ecological development.
Table 1. Diagnostic Indicators System of Eco-correlation between Cascade Development of Small and Micro Hydropower stations

\begin{tabular}{|c|c|c|}
\hline & & Minimum discharge \\
\hline & & Substitution effect \\
\hline & & $\begin{array}{c}\text { Emission reduction } \\
\text { effect }\end{array}$ \\
\hline & & $\begin{array}{c}\text { Degree of influence of } \\
\text { aquatic protected } \\
\text { species }\end{array}$ \\
\hline & $\begin{array}{l}\text { Environmental } \\
\text { character }\end{array}$ & $\begin{array}{l}\text { Construction of } \\
\text { fishway or fish value- } \\
\text { added discharge } \\
\text { dtation facilities }\end{array}$ \\
\hline & & $\begin{array}{c}\text { Terrestrial ecological } \\
\text { indicators } \\
\text { 1. species under } \\
\text { special protection } \\
\text { 2. human interference } \\
\text { 3. Bio-diversity } \\
\text { 4. Vegetation status } \\
\end{array}$ \\
\hline & & $\begin{array}{l}\text { Establishment of } \\
\text { Green hydropower } \\
\text { Construction ccheme } \\
\text { and dystem }\end{array}$ \\
\hline & & $\begin{array}{l}\text { he Matching of full- } \\
\text { time and part-time } \\
\text { managers }\end{array}$ \\
\hline $\begin{array}{l}\text { Diagnostic index } \\
\text { system of cascade }\end{array}$ & Manageability & $\begin{array}{l}\text { Input of green } \\
\text { hydropower } \\
\text { construction }\end{array}$ \\
\hline $\begin{array}{l}\text { ecological } \\
\text { correlation of small }\end{array}$ & & $\begin{array}{l}\text { Regular business } \\
\text { training }\end{array}$ \\
\hline $\begin{array}{l}\text { and micro } \\
\text { hydropower }\end{array}$ & & $\begin{array}{l}\text { Implementation of } \\
\text { remediation Facilities } \\
\text { for water quality and } \\
\text { biological impact of } \\
\text { rivers and reservoirs }\end{array}$ \\
\hline & & Resettlement planning \\
\hline & & $\begin{array}{l}\text { Implementation of } \\
\text { immigrant housing }\end{array}$ \\
\hline & & $\begin{array}{l}\text { Implementing the } \\
\text { income of migrants }\end{array}$ \\
\hline & Sociality & $\begin{array}{c}\text { Immigration } \\
\text { satisfaction }\end{array}$ \\
\hline & & $\begin{array}{l}\text { Implementation of } \\
\text { return of migrants }\end{array}$ \\
\hline & & $\begin{array}{l}\text { Influences of historical } \\
\text { and cultural heritage }\end{array}$ \\
\hline & & $\begin{array}{l}\text { Renewal of economic } \\
\text { and environmental } \\
\text { benefits of the old } \\
\text { system of small and } \\
\text { micro hydropower }\end{array}$ \\
\hline & Economy & $\begin{array}{c}\text { Economy of } \\
\text { development and } \\
\text { operation of water } \\
\text { resources scenic spots }\end{array}$ \\
\hline & & $\begin{array}{c}\text { Economy of tertiary } \\
\text { industry }\end{array}$ \\
\hline
\end{tabular}

There are many kinds of comprehensive evaluation methods, and different methods are from different perspectives to carry out comprehensive evaluation. Based on that only one method is used to evaluate the results, the credibility is low. Combination evaluation can make up for the shortcomings of various methods and give consideration to their advantages. It can be combined with analytic hierarchy process and fuzzy comprehensive evaluation method, which mainly embodies in dividing the evaluation index into hierarchical structure. The weights of each index are 
determined by analytic hierarchy process, and then the weights and fuzzy matrices are synthesized by weighted synthesis algorithm. Finally, the overall diagnosis and evaluation results are synthesized.

\section{Positive Measures for New Small Hydropower Development and Ecological Balance}

In order to develop small hydropower, we should make appropriate measures to local conditions, plan scientifically, and do a good job in the development and construction of small hydropower under the premise of protecting the ecological environment, so as to realize the sustainable utilization. The measures are as follows:

First, to establish a long-term and effective management mechanism for medium and small rivers, and to adopt modern scientific and technological information monitoring and control, it is necessary to maintain a certain amount of ecological water in each river. In dry season, hydropower stations can not operate without power outage, and ecological water in rivers must also be maintained. The state should introduce reasonable and strong regulations and penalty systems. Local governments must strictly enforce them.

The second is to establish a mechanism for water and soil conservation and ecological environment control in rivers, to ensure that each river is planned in a small area to promote the conversion of farmland to forests, to plant economic forests, fruits, Chinese herbal medicines and to expand forest cover, to avoid soil erosion, to reduce natural disasters, to breed a variety of wildlife, and to effectively protect the natural ecological environment, so as to enable destroye. The environment is restored to the primitive ecosystem.

Thirdly, after the hydropower development of each river basin has been realized, we must sacrifice some small and medium-sized micro-hydropower to restore the natural ecology of at least one or more rivers in the reservoir regulation area of each large hydropower station, enhance the ecological regulation of microregion and the return of aquatic organisms, and prohibit the planning and development of hydropower development. Rivers that have developed and built hydropower stations should also try to restore their ecology.

Fourth, to promote the renovation and technical transformation of old hydropower stations built and operated for decades in the last century, most of them must be re-regulated. Planning and design to meet the requirement of integrated self-configuration and integration with large power grid, four distances. Monitoring and intelligent power grid connection to improve modern middle and middle-sized power systems in an all-round way high-tech information technology innovation target for small and micro hydropower development, energy saving and emission reduction, low carbon and high efficiency, and protection of natural ecological environment.

Fifth, we should do a good job in resettlement, strengthen the overall planning of resettlement, strengthen management, and improve the public participation mechanism in resettlement.

In all, we should adhere to the development concept of ecological supremacy, adapt to the reasonable needs and eager expectations of the masses for a good water environment and water landscape, according to the characteristics of different regions, river basins and hydropower stations, focus on improving the coordinated development of hydropower stations and ecological environment, accelerate the transformation and upgrading of rural hydropower, and continuously improve the ecological efficiency of rural hydropower.

\section{Summary}

The diagnostic index system of small and micro hydropower cascade development and ecological correlation proposed in this paper covers four aspects: environmental, economic, managerial and social. The evaluation index system proposed in this paper is systematic and comprehensive, and relatively comprehensive and effective in practical application. In general, the utilization of hydropower resource is beneficial to ecological environment, not in contradiction with the protection of ecological environment. On the basis of ecological protection, the coordinated development of hydropower development and environmental protection can be realized. We must adhere to the protection principle, implement environmental protection measures in the whole process of hydropower planning, survey, design, construction and operation. Coordinating hydropower development planning with basin planning and ecological protection planning, taking environmental assessment of hydropower planning as the basic basis for hydropower development, minimizing adverse impacts on river ecological system, giving full play to positive roles in flood control, water replenishment, irrigation and reservoir area protection, and doing a good job in resettlement work. To achieve harmonious and optimum development in economic development, human and ecological balance.

\section{Acknowledgement}

Funded Project: Scientific Research Project of Sichuan Education Department (17SB0280)

\section{References}

1. Hydropower and the environment. IEA. https://www. ieahydro. org/publications/international-energy-agency-reports. 2018

2. International hydropower sustainability assessment protocol. IHA. 2018

3. Discussing the evaluation index and evaluation method of ecological environment impact of water conservancy and hydropower projects [J]. Li Guo. Science and technology and innovation. 2015 (18) 
4. Evaluation index system and evaluation method of ecological environment impact of water conservancy project $[\mathrm{J}]$. Yin Wanqin. Innovation and application of science and technology. 2015 (09)

5. Discussion on Environmental Protection Management of Water Conservancy and Hydropower Construction Sites [J]. Xu Yongren. Modern Economic Information. 2014 (16)

6. Study on Basin Ecological Compensation Mechanism in Main Functional Areas [J]. Zhang Huanan, Ge Yanxiang, Jiyumei. Modern Economic Discussion. 2017 (04)

7. Study on the Compensation Price of Rural Migrants'Land Expropriated by Hydropower Development [J]. Shangkai, Shi Guoqing, Wang Binbin. Price Theory and Practice. 2011 (03)

8. Berkamap G,Me Cartney M,Dugan P,et al. Dams,ecosystem functions and environmental restoration[A]. WCD thematic review environmental issue II. 1. 2000 